nghiệm trong nghiên cứu, giúp làm giảm đáng kể nguồn lực nghiên cứu đồng thời vẫn đạt được kết quả như mong đợi. Quan trọng hơn, qua việc xác lập các mô hình ảnh hưởng của biến độc lập xác định trên những tính chất vi cầu cụ thể, quy trình điều chế đã được kiểm soát.

\section{KẾT LUẬN}

Qua quá trình thực nghiệm, nghiên cứu đã xác định được mô hình ảnh hưởng của các thông số điều chế đến tính chất vi câu tạo thành. Bên cạnh đó, nghiên cứu đã thiết lập được các thông số tối ưu cụ thể để tạo được vi cầu ethyl cellulose chứa Metronidazol có độ câu 0,90 , tỷ lệ tải cao 14,44 (\%), kích thước trung bình phù hợp $153,14 \mu \mathrm{m}$, có đặc tính xốp với thể tích xốp $11,00 \mathrm{~mm}^{3} / \mathrm{g}$. Kết quả này giúp các nhà nghiên cứu kiểm soát được quy trình điều chế vi cầu xốp, qua đó có thể thiết kế quy trình phù hợp để tạo được vi cầu xốp có đặc tính định trước.
LỜI CẢM ƠN. Nghiên cứu này được tài trợ bởi Đại học Y Dược Thành phố Hồ Chí Minh theo hợp đồng nghiên cứu số 37/2019/HĐ-ĐHYD.

\section{TÀI LIÊU THAM KHẢO}

1. Park J., Ye M., Park K. (2005), "Biodegradable polymers for microencapsulation of drugs", Molecules, 10(1), 146-161.

2. Minh-Quan L., Violet F., Paniagua $C_{\text {., }}$ et al. (2018), Penta-block copolymer microspheres: Impact of polymer characteristics and process parameters on protein release, International Journal of Pharmaceutics, 535,428-437.

3. Freitas S., Merkle H., Gander B. (2005), "Microencapsulation by solvent extraction/evaporation: reviewing the state of the art of microsphere preparation process technology", Journal of Controlled Release, 102(2), 313-332.

4. Li M., Rouaud O., Poncelet D. (2008), "Microencapsulation by solvent evaporation: state of the art for process engineering approaches", International journal of pharmaceutics, 363(1-2), 26-39.

\title{
KHẢO SÁT KIẾN THỨC VỀ BÊ̂NH VIÊM TAI GIỮA CỦA BỐ MẸ Có CON DƯớI 5 TUỔI HUYÊ̂N AN DƯƠNG, HẢI PHÒNG
}

Tạ Hùng Sơn*

\section{TÓM TẮT}

Mục tiêu: Khảo sát kiến thứcvề bệnh viêm tai giữa (VTG) của bố mẹ có con dưới 5 tuổi. Đối tượng và phương pháp nghiên cứu: mô tả cắt ngang qua phỏng vấn 2000 bố mẹ trẻ tại huyện An Dương - Hải Phòng. Kết quả: Phần lớn bố me trẻ tiếp cânn thông tin qua internet $(92,7 \%)$ và truyền miệng $(89,7 \%)$, các phương tiện chính thống chỉ chiếm tỉ lệ dưới $50 \%$; có $47,6 \%$ bố mẹ trẻ hiểu về bệnh VTG, 39,9\% hiểu vế nguyên nhân gấy VTG, số bố mẹ hiểu sai về các chăm sóc khi trẻ bị VTG chiếm tỉ lệ cao. Kết luận: Kiến thức của bố mẹ trẻ về bệnh VTG còn thấp và bị ảnh hưởng nhiều của internet và kênh truyền miệng. Kiến nghị: Cần tuyên truyền nâng cao kiến thức của bố mẹ về bệnh VTG qua các kênh thông tin chính thống như y tế xã phường và các cơ sở y tế.

Tứ khóa: Viêm tai giữa, trẻ em dưới 5 tuổi, kiến thức của bố mẹ trẻ.

\section{SUMMARY \\ SURVEY ON KNOWLEDGE OF OTITIS MEDIA OF PARENTS WHITH CHILDREN}

\footnotetext{
*Đại học Y Dược Hải Phòng

Chịu trách nhiệm chính: Tạ Hùng Sơn

Email: dr.hungson@gmail.com

Ngày nhận bài: 18.10.2021

Ngày phản biện khoa học: 14.12.2021

Ngày duyệt bài: 22.12.2021
}

\section{UNDER 5 YEARS OLD IN ANDUONG DISTRICT - HAIPHONG}

Objectives: Survey on knowledge about otitis media (OM) of parents with children under 5 years old.. Study design: a cross-sectional study. Results The majority of young parents access information via the internet $(92.7 \%)$ and word of mouth $(89.7 \%)$, official means account for less than $50 \%$; There are $47.6 \%$ of young parents understand about OM, 39.9\% understand about the causes of $\mathrm{OM}$, a high percentage of parents misunderstand about care for children with OM. Conclusion : The knowledge of young parents about $\mathrm{OM}$ is still low and is heavily influenced by the internet and word of mouth. Recommendation: It is necessary to propagate and improve the knowledge of parents about OM through official communication channels such as community health centers and health facilities.

Key words: OM, knowledge, children under 5 years old

\section{I. ĐĂT VẤN ĐỀ}

Viêm tai giữa là một bệnh rất thường gặp và xuất hiện sớm ở trẻ em dưới 5 tuổi, là một bệnh chỉ đứng sau nhóm bệnh đường hô hấp và cũ̃ng là nguyên nhân phổ biến khiến trẻ phải đi khám bệnh. Bệnh liên quan mật thiết với các bệnh lý của đường hô hấp trên và được xem như là một biến chứng của viêm đường hổ hấp trên do virus (vURI). Hiểu biết về bệnh cũng như cách phòng 
ngừa và chăm sóc khi trẻ bị bệnh là rất quan trọng, nó ảnh hưởng đến tỉ lệ mắc, tỉ lệ biến chứng và di chứng của bệnh. Do đó chúng tôi thực hiên nghiên cứu này với mục tiêu:

Khảo sát kiến thứcvề bệnh viêm tai giữa của bố me có con dưới 5 tuổi.

\section{II. ĐỐI TƯỢNG VÀ PHƯƠNG PHÁP NGHIÊN CỨU}

2.1. Đối tượng nghiên cứu: bố hoặc me của 2000 trẻ tại huyện An Dương - thành phố Hải Phòng trong khoảng thời gian từ tháng 4 đến tháng 6 năm 2015.

\subsection{Phương pháp nghiên cứu} mô tả

- Thiết kế nghiên cứu: nghiên cứu cắt ngang

- Cõ̃ mẫu: Áp dụng công thức tính cõ mẫu

$$
\mathrm{n}=Z_{\propto / 2}^{2} \frac{p(1-p)}{d^{2}}
$$

Trong đó: chọn khoảng tin cậy là 99\%; độ sai lệch mong muốn là $0,05 \%$ thì ${ }^{2}{ }^{2} / 2=1,96^{2}$

$d^{2}=0,01$.

Lây $p=0,05$ theo tỉ lệ bệnh viêm tai giữa trong nghiên cứu của tác giả Đặng Văn Chức năm 2013 nghiên cứu mô hình bệnh tật trẻ dưới 5 tuổi tại huyện An Lão.

Thay vào công thức ta có số trẻ cần nghiên cứu là 1825 trẻ.
- Kỹ thuât thu thâp số liêu: Bố me trẻ được phỏng vấn theo bộ câu hỏi có sẵn bởi các bác sĩ chuyên khoa tai mũi họng đã được tập huấn kỹ lương.

- Xử lý số liệu: theo phương pháp thống kê $y$ học, sử dụng phần mềm SPSS 18.0.

- Thời gian nghiên cứu: tháng 4 đến tháng 6 năm 2015.

\section{KẾT QUẢ NGHIÊN CỨU}

Bảng 3.1. Phương thức tiếp cận thông tin của bố, me tré $(n=2000)$

\begin{tabular}{|c|c|c|}
\hline Phương thức tiếp cận & $\begin{array}{c}\text { Số lượng } \\
\text { (n) }\end{array}$ & Tỉ lệ (\%) \\
\hline Radio (đài) & 0 & 0 \\
\hline Tivi & 793 & 39,7 \\
\hline Mạng Internet & 1853 & 92,7 \\
\hline Loa truyền thanh & 889 & 44,5 \\
\hline Sách báo, tờ rơi & 208 & 10,4 \\
\hline Y tế xãa, thôn bản & 561 & 28,1 \\
\hline Truyền miệng & 1793 & 89,7 \\
\hline Họp dân phố, họp thôn & 0 & 0 \\
\hline
\end{tabular}

Nhân xét: Đối tượng nghiên cứu tiếp cận thông tin chủ yếu qua Internet $(92,7 \%)$, sau đó là nghe người khác truyền đạt kinh nghiệm (Truyền miệng: $89,7 \%$ ). Các phương pháp còn lại lần lượt gồm Loa truyền thanh $(44,5 \%)$, Tivi $(39,7 \%)$, y tế xã $(28,1)$ và qua sách báo, tờ rơi là $10,4 \%$.

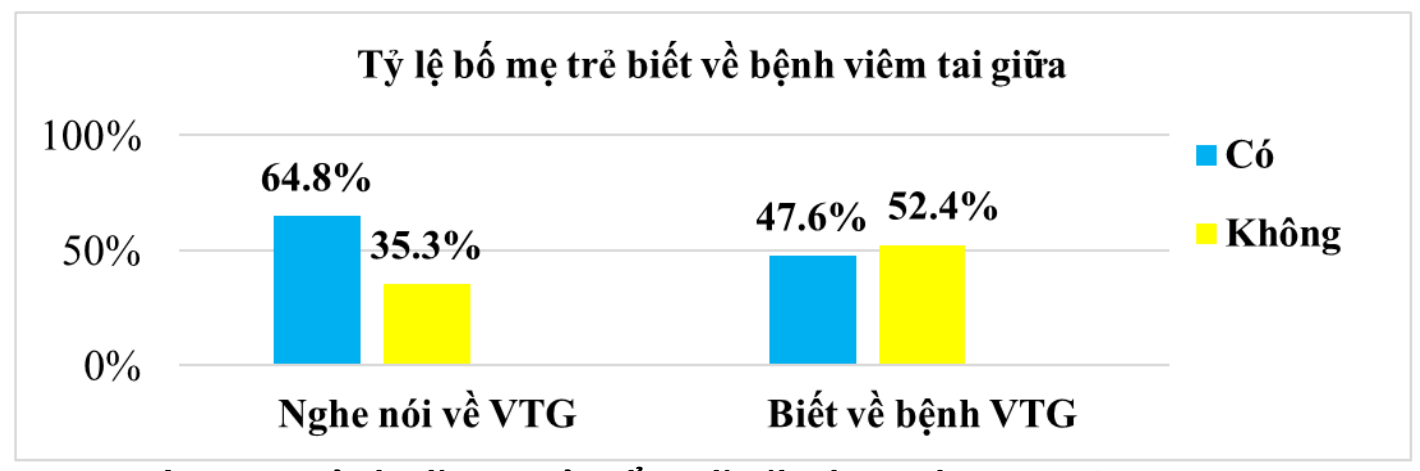

Hình 3.1. Tỷ lể bố, me trẻ hiểu biêt về bệnh viêm tai giữa $(n=2000)$

Nhận xét: Trong 2000 bố mẹ trẻ tham gia vào nghiên cứu, có 1295 người đã từng nghe nói đến bệnh viêm tai giữa $(64,8 \%)$ nhưng số lượng bố mẹ trẻ thật sự biết về bệnh viêm tai giữa là 952 người $(47,6 \%)$. Vẫn còn $52,4 \%$ bố mẹ trẻ chưa biết về bệnh lý viêm tai giữa ở trẻ nhỏ.

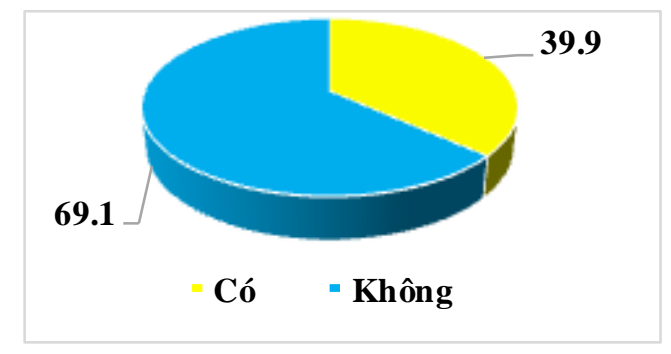

Hình 3.2. Tỷ lệ bố, mẹ trẻ biêt về nguyên nhân gây viêm tai giữa $(n=2000)$

Nhận xét: Tỷ lệ bố me trẻ biết về nguyên nhân gây viêm tai giữa thấp hơn tỷ lệ bố mẹ trẻ không biết (39,9\% so với 69,1\%). 


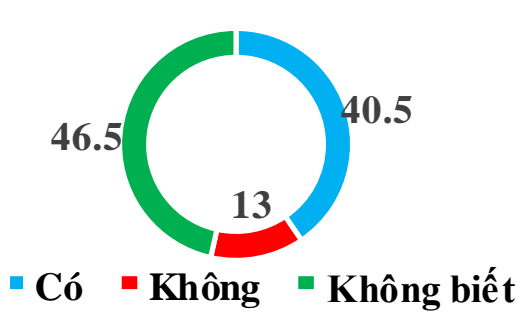

Hình 3.3. Tỷ lệ bố, me trẻ biêt về phòng bệnh viêm tai giữa $(n=2000)$

Nhận xét: Về phòng bệnh viêm tai giữa, có $40,5 \%$ bố mẹ trẻ trả lời đây là bệnh có thể dự phòng được, $13 \%$ trả lời không thể phòng bệnh được và vẫn còn $46,5 \%$ không biết về phòng bệnh viêm tai giữa.

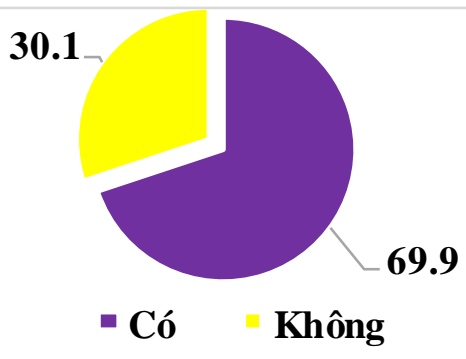

Hình 3.4. Tỷ lệ bố, me trẻ biêt về chữa bệnh viêm tai giữa $(n=2000)$

Nhận xét: Về chữa bệnh viêm tai giữa, $69,9 \%$ bố me trẻ có câu trả lời VTG là bênh có thể chữa được và $30,1 \%$ cho rằng đây là bệnh không chữa được.

Bảng 3.2. Kiến thức đúng của bố mẹ trẻ về bệnh viêm tai giữa (n=619)

\begin{tabular}{|c|c|c|c|c|}
\hline \multirow{2}{*}{ Kiến thức } & \multicolumn{2}{|c|}{$\begin{array}{c}\text { Đúng } \\
\end{array}$} & \multicolumn{2}{|c|}{ Sai } \\
\hline & Số lượng (n) & Tỉ lệ (\%) & Số lượng (n) & Tỉ lệ (\%) \\
\hline \multicolumn{5}{|c|}{ Biếu hiện bệnh } \\
\hline Chảy mủ tai & 617 & 64,8 & 335 & 35,2 \\
\hline Đau tai (quấy khóc + quờ tai) & 731 & 76,8 & 221 & 23,2 \\
\hline Sốt & 815 & 85,6 & 137 & 14,4 \\
\hline \multicolumn{5}{|c|}{ Nguyên nhân bệnh } \\
\hline Do viêm mũi họng & 408 & 65,9 & 211 & 34,1 \\
\hline Do xì mũi & 0 & 0 & 619 & 100 \\
\hline Do bơm rửa mũi & \begin{tabular}{|c|}
0 \\
\end{tabular} & 0 & 619 & 100 \\
\hline \multicolumn{5}{|c|}{ Phương pháp phòng bệnh } \\
\hline Điều trị đúng các bệnh mũi họng & $\begin{array}{l}79 \\
\end{array}$ & 7,4 & 990 & 92,6 \\
\hline \multicolumn{5}{|c|}{ Điều trị bệnh } \\
\hline Dùng kháng sinh & 1195 & 85,5 & 203 & 14,5 \\
\hline Đặt thông khí màng nhĩ & 102 & 7,3 & 1296 & 92,7 \\
\hline
\end{tabular}

Nhận xét: Khi khảo sát kiến thức của bố mẹ trẻ về bệnh viêm tai giữa, tỷ lệ bố mẹ trẻ đúng về các biểu hiên của bênh lần lượt là Sốt $(85,6 \%)$; Đau tai (quây khóc + quờ tai) $(76,8 \%)$; Chảy mủ tai $(64,8 \%)$. Tỷ lệ bố mẹ trẻ đúng về nguyên nhân gây bệnh là do viêm mũi họng đtạ tỷ lệ $65,9 \%$, đặc biệt không có bố mẹ nào biết việc xì mũi và bơm rửa mũi là nguyên nhân gây bệnh. Về phương pháp phòng bệnh, chỉ có $7,4 \%$ có kiến thức đúng còn lại $92,6 \%$ có kiến thức sai. Về kiến thức điều trị bệnh; $85,5 \%$ đúng về phương pháp sử dụng kháng sinh nhưng chỉ có $7,3 \%$ biết về phương pháp Đặt thông khái màng nhĩ.

Bảng 3.3. Kiến thức sai của bố mẹ trẻ về bệnh viêm tai giữa (n=619)

\begin{tabular}{|c|c|c|c|c|}
\hline \multirow{2}{*}{ Kiến thức } & \multicolumn{2}{|c|}{ Đúng } & \multicolumn{2}{|c|}{ Sai } \\
\hline & Số lượng (n) & Tỉ lệ (\%) & Số lượng (n) & Tỉ lệ (\%) \\
\hline \multicolumn{5}{|c|}{ Biếu hiện bệnh } \\
\hline Nghe kém & 283 & 29,7 & 669 & 70,3 \\
\hline U tai & 283 & 29,7 & 669 & 70,3 \\
\hline \multicolumn{5}{|c|}{ Nguyên nhân bệnh } \\
\hline Nước vào tai & 615 & 99,4 & 4 & 0,6 \\
\hline Do ngoáy tai & 240 & 38,8 & 379 & 61,2 \\
\hline \multicolumn{5}{|c|}{ Phương pháp phòng bệnh } \\
\hline Thường xuyên lấy ráy tai & 600 & 56,1 & 469 & 43,9 \\
\hline Rửa tai bắng nước muối sinh lý & 0 & 0 & 1069 & 100 \\
\hline Rửa tai bằng oxy già & 66 & 6,2 & 1003 & 93,8 \\
\hline Tránh nước vào tai & 810 & 75,8 & 259 & 24,2 \\
\hline
\end{tabular}


VIETNAM MEDICAL JOURNAL N¹ - JANUARY - 2022

\begin{tabular}{|c|c|c|c|c|}
\hline \multicolumn{5}{|c|}{ Điều trị bệnh } \\
\hline Rắc thuốc làm khô tai & 1116 & 79,8 & 282 & 20,2 \\
\hline Nhỏ oxy già vào tai & 135 & 9,7 & 1263 & 90,3 \\
\hline Thối thuốc vào tai & 313 & 22,4 & 1085 & 77,6 \\
\hline
\end{tabular}

Nhân xét: Khi khảo sát kiến thức của bố mẹ trẻ về bệnh viêm tai giữa, tỷ lệ bố mẹ trẻ sai khi nhầm lẫn về biểu hiện, nguyên nhân, phòng bệnh và điêuu trị bệnh viêm tai giữa. Cụ thể có $29,7 \%$ sai khi cho rằng ù tai và nghe kém là 2 biểu hiện của viêm tai giữa. Có sự nhâm lẫn khi cho rằng Tránh nước vào tai $(75,8 \%)$; Thường xuyên lấy ráy tai $(56,1 \%)$ là các biện pháp phòng bệnh viêm tai giữa. Bố mẹ trẻ cũng sai khi cho rằng Nước vào tai $(99,4 \%)$; Do ngoáy tai $(38,8 \%)$ là nguyên nhân gây ra viêm tai giữa. Cũng có sự nhầm lẫn về phương pháp điều trị bệnh khi cho rằng Rắc thuốc làm khô tai $(79,8 \%)$; Thổi thuốc vào tai $(22,4 \%)$ và Nhỏ oxy già vào tai $(9,7 \%)$ có thể điều trị viêm tai giữa.

Bảng 3.4. Kiến thức sai của bố mẹ trẻ về cách xư trí khi trẻ bị chảy mủ tai $(n=2000)$

\begin{tabular}{|c|c|c|c|}
\hline \multicolumn{1}{|c|}{ Kiến thức } & Đúng & Sai & Không biết \\
\cline { 2 - 4 } & Số lượng(\%) & Số lượng(\%) & Số lượng (\%) \\
\hline Chảy mủ tai có dùng thuốc nhỏ vào tai trẻ không? & $557(27,9)$ & $494(24,7)$ & $949(47,4)$ \\
\hline $\begin{array}{c}\text { Chảy mủ tai có dùng nước muối sinh lý rửa tai trẻ } \\
\text { không? }\end{array}$ & $470(23,5)$ & $619(31)$ & $911(45,5)$ \\
\hline Chảy mủ tai có dùng thuốc bột làm khô tai trẻ không? & $568(28,4)$ & $422(21,1)$ & $1010(50,5)$ \\
\hline Chảy mủ tai có cân tránh nước vào tai trẻ không? & $1647(82,3)$ & $0(0)$ & $353(17,7)$ \\
\hline
\end{tabular}

Nhân xét: Khi trẻ bi chảy mủ tai; có $82,3 \%$ bố me trẻ sai khi cho rằng cần tránh nước vào tai trẻ; $28,4 \%$ cho rằng cân dùng thuốc bột làm khô tai trẻ; $27,9 \%$ cho rằng cân phải dùng thuốc nhỏ vào tai trẻ khi chảy mủ và $23,5 \%$ cho là đúng khi dùng nước muối sinh lý rửa tai cho trẻ. Tỷ lệ bố mẹ trẻ không biết chiếm tỷ lệ cao, cụ thể Dùng thuốc bột làm khô tai trẻ $(50,5)$; Dùng nước muối sinh lý rửa tai $(45,5)$; Dùng thuốc nhỏ vào tai trẻ $(47,4 \%)$.

\section{BÀN LUÂN}

Kết quả nghiên cứu cho thấy đối tượng nghiên cứu tiếp cận thông tin chủ yếu qua Internet $(92,7 \%)$ và truyên miệng $(89,7 \%)$, khác với nghiên cứu của các tác giả Vũ Văn Sản và cộng sự cho thấy phương tiện tiếp cận thông tin và tự tìm hiểu thông tin ở các bà mẹ chủ yếu thông qua cán bộ cộng đồng, sách báo tranh ảnh, cán bộ y tế. Sự khác biệt này có thể giải thích do thời gian nghiên cứu của 2 nghiên cứu khác nhau nên sự phát triển của công nghệ thông tin, mạng Internet có sự khác biệt.

Trong 2000 bố mẹ trẻ tham gia vào nghiên cứu, có 1295 người đã từng nghe nói đến bệnh viêm tai giữa $(64,8 \%)$ nhưng số lượng bố mẹ trẻ thật sư biết về bệnh viêm tai giữa là 952 người $(47,6 \%)$. Vẫn còn $52,4 \%$ bố mẹ trẻ chưa biết về bệnh lý viêm tai giữa ở trẻ nhỏ. Về phòng bệnh viêm tai giữa, có $40,5 \%$ bố mẹ trẻ trả lời đây là bệnh có thể dự phòng được, 13\% trả lời không thể phòng bệnh được và vẫn còn 46,5\% không biết về dự phòng viểm tai giữa như thế nào? Vể chữa bệnh viêm tai giữa, 69,9\% bố mẹ trẻ có câu trả lời VTG là bênh có thể chữa được và $30,1 \%$ cho rằng đây là bênh không chữa được. Tỷ lệ bố mẹ trẻ đúng về nguyên nhân gây bệnh là do viêm mũi họng đtạ tỷ lệ 65,9\%, đặc biệt không có bố mẹ nào biết việc xì mũi và bơm rửa mũi là nguyên nhân gây bệnh. Về phương pháp phòng bệnh, chỉ có $7,4 \%$ có kiến thức đúng còn lại $92,6 \%$ có kiến thức sai. Về kiến thức điêuu trị bệnh; $85,5 \%$ đúng về phương pháp sư dụng kháng sinh nhưng chỉ có $7,3 \%$ biết về phương pháp Đặt thông khí màng nhĩ. Khi khảo sát kiến thức của bố mẹ trẻ vê bệnh viêm tai giữa, tỷ lệ bố mẹ trẻ sai khi nhâm lẫn về biểu hiện, nguyên nhân, phòng bệnh và điêu trị bệnh viêm tai giữa. Kết quả nghiển cứu của chúng tôi khác với nghiên cứu của các tác giả Vũ Văn Sản và cộng sự khi nghiên cứu về kiến thức, thái độ xử trí của bà mẹ về viêm tai giữa ở trẻ nhỏ tuổi học đường tại bệnh viện trẻ em Hải Phòng khi chỉ có 4,5\% bà mẹ biết dấu hiệu viêm tai giữa, 46,6\% cho rằng viêm tai giữa là do virus/vi khuẩn, 38,3\% cho rằng viêm tai giữa gây biến chứng viêm phổi. Qua khảo sát kiến thức của bố mẹ có con dưới 5 tuổi chúng tôi phát hiện ra vấn đề lớn có ảnh hưởng nghiêm trọng đến quá trình nhận thức về bênh lý viêm tai giữa: nguyên nhân, biểu hiện, dự phòng và điêu trị bệnh. Tỷ lệ bố mẹ trẻ có kiến thức đúng chiếm tỷ lệ thấp, tỷ lệ bố mẹ không biết về bệnh lý này khá cao và đáng ngại hơn tỷ lệ bố mẹ có kiến thức sai về bệnh lại đang chiếm đa số. Họ luôn cho rằng những kiến thức của mình có về bệnh là đúng và điều này gây nguy hiểm cho trẻ khi bố mẹ áp dụng kiến thức của mình thành các hoạt động thực hành 
cho trẻ. Nghiên cứu của chúng tôi có kết quả tương đồng với một số nghiên cứu trong và ngoài nước. Các nghiên cứu đã thực hiện cũng chỉ ra các khoảng trống kiến thức và nhưng sai lầm trong kiến thức của bố mẹ, người chăm sóc trẻ về bệnh lý viêm tai giữa. Malene Plejdrup Hansen năm 2015 nghiên cứu về kiến thức và niềm tin của cha mẹ ở Austraylia về việc quản lý bệnh VTG cấp tính ở trẻ em. Nhiều phụ huynh không có hiểu biết chính xác về nguyển nhân gây VTG cấp tính.

\section{KẾT LUÂN}

Kiến thức của bố me trẻ về bệnh VTG còn thấp ( $<50 \%$ hiểu đúng) và bị ảnh hưởng nhiều của internet $(92,7 \%)$ và kênh truyền miệng $(89,7 \%)$.

\section{KIẾN NGH!}

Cần tuyên truyền nâng cao kiến thức của bố me về bệnh VTG qua các kênh thông tin chính thống như y tế xã phường và các cơ sở y tế.
TÀl LIẸU THAM KHẢO

1. Vũ Văn Sản, Đoàn Thị Hồng Hoa, Đoàn Thị Nguyệt Ánh, Nghiên cứu kiến thức, thái độ xử trí của bà me về viêm tai giữa ở trẻ nhỏ tuổi học đường tại bệnh viện trẻ em Hải Phòng, Tạp chí y học thực hành 2013.

2. Afolabi, O.A., et al., Socioeconomic challenges of chronic suppurative otitis media management in state tertiary health facility in Nigeria. Egyptian Journal of Ear, Nose, Throat and Allied Sciences, 2014. 15(1): p. 17-22.

3. Hansen, M.P., Howlett, J., Del Mar, C. et al. Parents' beliefs and knowledge about the management of acute otitis media: a qualitative study. BMC Fam Pract 16, 82 (2015).

4. Kathleen A. Daly, P.R.E.S., MPH*; and Bruce Lindgren, MS $\neq$, Knowledge and Attitudes About OM Risk Implications for Prevention. paediatric, 1997. 100(6): p. 931.

5. Nowak-Adamska E, e.a., Risk factors and selected aspects of pathogenesis and treatment of acute otitis media in children: A clinical and audiological analysis of 311 cases. Ortorynolaryngologia, 2014. 13(2): p. 105-113.

\title{
HIỄU QUẢ CỦA PHƯƠ'NG PHÁP HOẠT HÓA NOÃN NHÂN TAOO CHỦ ĐộNG VÀ Bİ ĐộNG
}

\author{
Diêm Thị Yến, Lê Thị Phương Lan, Nguyễn Thị Cẩm Vân, \\ Nguyễn Thị Như Trang, Trần Huệ Trân, Trương Văn Hạnh, \\ Nguyễn Vũ Hà, Hoàng Thị Phương, Vũ Thị Liên(*)
}

\section{TÓM TẮT}

Đăt vấn đề và mục tiêu: Măc dù phương pháp tiêm tînh trùng vào bào tương noãn (ICSI) đã cải thiện tỷ lệ thu tinh ống nghiệm trong những năm gần đây, tuy nhiển, vẫn có tỷ lệ khoảng 1-5\% số ca thất bại thụ tinh hoàn toàn sau ICSI. Việc kết hợp kỹ thuật hoạt hóa hóa noãn ( $A O A)$ và ICSI đã giúp cải thiện tỳ lệ thụ tinh. Mặc dù vây, chỉ định cho kỹ thuật $A O A$ rất khác nhau ở các nghiên cứu đã được công bố. Nghiên cứu này được tiến hành với mục tiêu đánh giá hiệu quả lâm sàng của việc áp dụng kỹ thuật $A O A$ chủ động và thụ động trên các nhóm bệnh nhẩn cụ thể. Phương pháp nghiên cứu: Nghiên cứu hồi cứu tiến hành trên 427 noãn của 57 cặp vợ chông đến làm thụ tinh ống nghiệm tại Trung tâm IVF, Vinmec Times City. Kỹ thuật $A O A$ chủ động được áp dụng cho nhóm bệnh nhân có tiền sử thụ tinh kém hoặc chất lượng tinh trùng yếu. Kỹ thuật $A O A$ bị động được tiến hành trên nhóm bênh nhân có noãn non nuôi trưởng thành trong phòng thí nghiệm hoặc có tỷ lệ thụ tinh kém ở

(*)Trung tâm ART, Bệnh viện Vinmec Times City Chịu trách nhiệm chính: Diểm Thị Yến

Email: drdiemyen@gmail.com

Ngày nhận bài: 25.10.2021

Ngày phản biện khoa học: 20.12.2021

Ngày duyệt bài: 28.12.2021 ngày thứ nhất sau ICSI (D1). Kết quả: Ở nhóm AOA chủ động, tỷ lệ thụ tinh đạt cải thiện một các rõ rệt và đạt $79 \%$ ở trên các bệnh nhân có tiền sử thụ tinh kém $(<50 \%)(p<0,05)$. Với nhóm AOA bi động, những bệnh nhân có tỷ lệ thụ tinh thấp ở ngày $\mathrm{D} 1(<50 \%)$, sau khi áp dụng AOA tỷ lệ thụ tinh tăng lên một cách có ý nghĩa và đạt $76,5 \%(p<0,05)$; với nhóm noãn trưởng thành trong phòng thí nghiêm, tỷ lê thu tinh của nhóm có $A O A$ và không $A O A$ lần lượt là $67,61 \%$ và $50 \%$, sự khác biệt này là có ý nghĩa thống kê $(p<0,05)$. Kết luận: AOA không những hiệu quả khi áp dụng chủ động trên nhóm bệnh nhân có tiền sử thư tinh kém và chất lượng tinh trùng yếu, mà còn có thể thực hiên bi động với nhóm bệnh nhân có tỷ lệ thụ tinh kém ở ngày D1 và với nhóm noãn nuôi trưởng thành trong phòng thí nghiệm. Tác đông lâu dài của $\mathrm{AONA}$ đến sự phát triển của thai nhi và trẻ sinh sống vẫn còn đang được nghiên cứu, do đó, kỹ thuật $A O A$ không nên được thực hiện một các thường quy cho tất cả các ca, mà chỉ nên cần nhắc thực hiện khi thực sự cần thiết.

\section{SUMMARY}

THE EFFECT AND APPLICATIONS FOR ACTIVE ARTIFICIAL OOCYTE ACTIVATION (AOA) AND RESCUE AOA

Background and aims: In spite of the success of intracytoplasmic sperm injection (ICSI), the total 